Geo-Resources JGSH Aา Journal of Geology and Mineral Resources Center for Geological Survey, Geological Agency, Ministry of Energy and Mineral Resources Journal homepage: http://jgsm.geologi.esdm.go.id

\title{
Potensi Geologi Daerah Banten dan Sekitarnya Berdasarkan Analisis Data
} Anomali Gayaberat

\section{Geological Potential in Banten and Surrounding Area Based on Gravity Anomaly Data Analysis}

\author{
M. Ervan dan Subagio \\ Pusat Survei Geologi, Jalan Diponegoro No.57 Bandung \\ email: m_ervan@yahoo.com \\ Naskah diterima : 21 Juli 2021, Revisi terakhir : 15 September 2021 Disetujui : 16 September 2021, Online : 16 September 2021 \\ DOI: http://dx.doi.org/10.33332/jgsm.geologi.22.3.165-175p
}

\begin{abstract}
Abstrak-Potensi geologi daerah Banten dan sekitarnya dianalisis berdasarkan interpretasi anomali gayaberat, baik potensi positif (sumberdaya mineral) maupun potensi negatif (kebencanaan geologi). Data anomali gayaberat yang digunakan untuk analisis potensi tersebut berupa anomali Bouguer dan anomali sisa. Kedua pola anomali ini di beberapa lokasi mempunyai hubungan langsung yang dapat dianalisis keterikatannya, sehingga memberikan pemahaman tentang hubungan struktur geologinya. Beberapa contoh, seperti Cekungan Jakarta dan Cekungan Ujung Kulon (merupakan bagian dari potensi geologi yang positif) dapat dianalisis dari kedua anomali di atas. Contoh lainnya adalah struktur geologi sesar geser (merupakan bagian dari potensi geologi negatif) berarah hampir baratlaut-tenggara. Sesar ini dapat diamati dari pola anomali Bouguer dan pola anomali sisa. Oleh sebab itu, dapat disimpulkan bahwa struktur geologi yang membentuk fenomena tersebut merupakan struktur dalam yang menerus hingga ke permukaan
\end{abstract}

Katakunci: Anomali gayaberat, Cekungan Jakarta, Cekungan Ujung Kulon, potensi negatif, potensi positif, sesar geser.

\begin{abstract}
The geological potential in Banten and surrounding area was analyzed based on interpretation of gravity anomaly, both the positive potential (mineral resources) and the negative potential (geological disaster). The gravity anomaly used for the potential analysis are Bouguer anomaly and residual anomaly. These two anomaly patterns in several locations have relationship that can be analyzed for their attachments, thus providing an understanding the relationship of the geological structure. Some examples, include the Jakarta Basin and the Ujung Kulon Basin (part of the positive geological potential) that can be analyzed from the two anomalies above. Another example is about the geological structure ofthe strike slip fault (which is part of the negative geological potential) trending almost northwest-southeast. This fault can be identified from the Bouguer anomaly and the residual anomaly patterns. Therefore, it can be concluded that the geological structure creating the phenomena is a deep structure that continues to the surface.
\end{abstract}

Keywords: Gravity anomaly, Jakarta Basin, Ujung Kulon Basin, negative potential, positive potential, strike-slip fault. 


\section{PENDAHULUAN}

Pemetaan geologi dan geofisika dilakukan di daerah penelitian sejak tahun 1970 hingga tahun 1985 oleh Direktorat Geologi Bandung (kini bernama Pusat Survei Geologi). Pemetaan dilaksanakan secara sistematik berskala 1:100.000, mencakup Lembar Anyer, Lembar Serang, Lembar Leuwidamar, Lembar Cikarang, dan Lembar Ujungkulon. Pemetaan ini bertujuan untuk memberikan gambaran geologi daerah penelitian secara regional, sehingga dapat dimanfaatkan untuk eksplorasi sumberdaya geologi, yang sifatnya positif (sumberdaya energi dan mineral) dan negatif (kebencanaan geologi), serta untuk keperluan penelitian kebumian lainnya. Berdasarkan data geologi/geofisika regional ini dapat dilakukan deliniasi daerah yang diperkirakan mempunyai prospek terhadap sumberdaya geologi tersebut, sehingga kemudian dapat ditindak lanjuti dengan penelitian yang lebih rinci.

Penelitian lainnya dilakukan oleh beberapa ahli kebumian, antara lain adalah: Sudarman (1985) melakukan penelitian panas bumi di wilayah geotermal Citaman berdasarkan data geomagnet, data geolistrik, data magneto-telluric, dan data gradien termal. Simamora (2006) melakukan penelitian geomagnet untuk keperluan eksplorasi zona mineralisasi di daerah Malingping, Bayah, dan sekitarnya, Kabupaten Lebak. Subagio dan Widijono (2008) telah melakukan survei gayaberat untuk penelitian panas bumi di wilayah Pandeglang dan sekitarnya.
Mengacu kepada hasil penelitian para peneliti tersebut di atas, penulis bermaksud untuk melakukan penelitian lebih lanjut tentang potensi geologi daerah Banten, dalam hubungannya dengan pola anomali gayaberat, sehingga dapat dilakukan penafsiran secara kualitatif maupun kuantitatif, tentang potensi geologi yang sifatnya positif (sumberdaya energi dan mineral) maupun negatif (kebencanaan geologi, Badan Geologi, 2009; dalam Subagio, 2013).

Lokasi penelitian terletak di wilayah ujung barat Pulau Jawa, tepatnya berada di daerah administrasi Provinsi Banten (Gambar 1).

\section{TATAAN GEOLOGI DAERAH PENELITIAN}

Fisiografi dan morfologi daerah penelitian mempunyai beberapa satuan morfologi, yaitu dataran rendah, dataran rawa danau, perbukitan bergelombang, dan daerah pegunungan serta krucut gunungapi (Atmawinata \& Abidin, 1991; Sudana \& Santosa, 1991; Santosa, 1992, Sujatmiko \& Santosa, 1992, Rusmana dkk., 2012).

Secara regional, tatanan geologi daerah penelitian tersaji dalam Gambar 2, terdiri atas endapan permukaan, batuan sedimen Kuarter dan Paleogen-Neogen, batuan gunungapi Kuarter dan Paleogen-Neogen, batuan terobosan Paleogen-Neogen serta batuan malihan. Endapan permukaan terdiri atas endapan sungai dan pantai, serta endapan rawa, yang tersebar secara meluas di sepanjang pantai utara, barat, dan pantai selatan daerah penelitian.

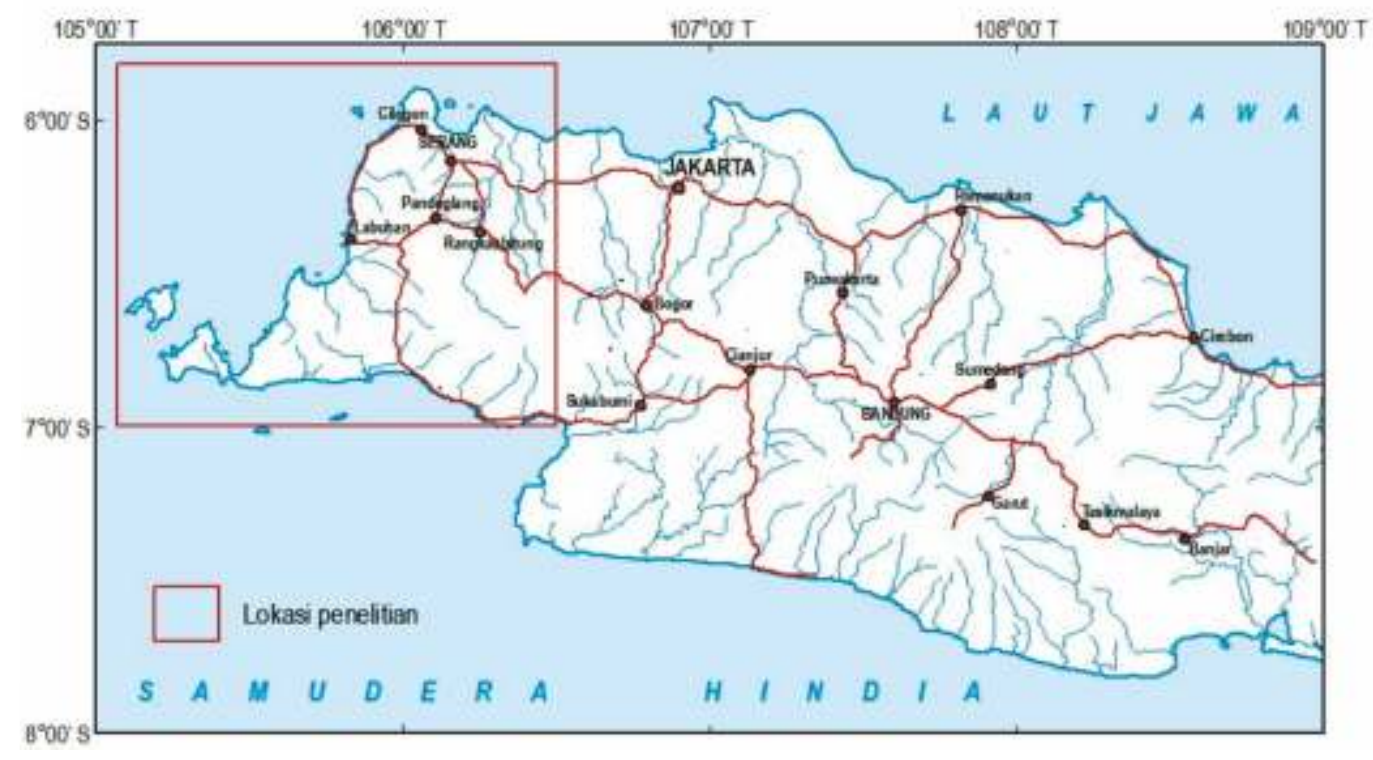

Gambar 1. Lokasi daerah penelitian. 


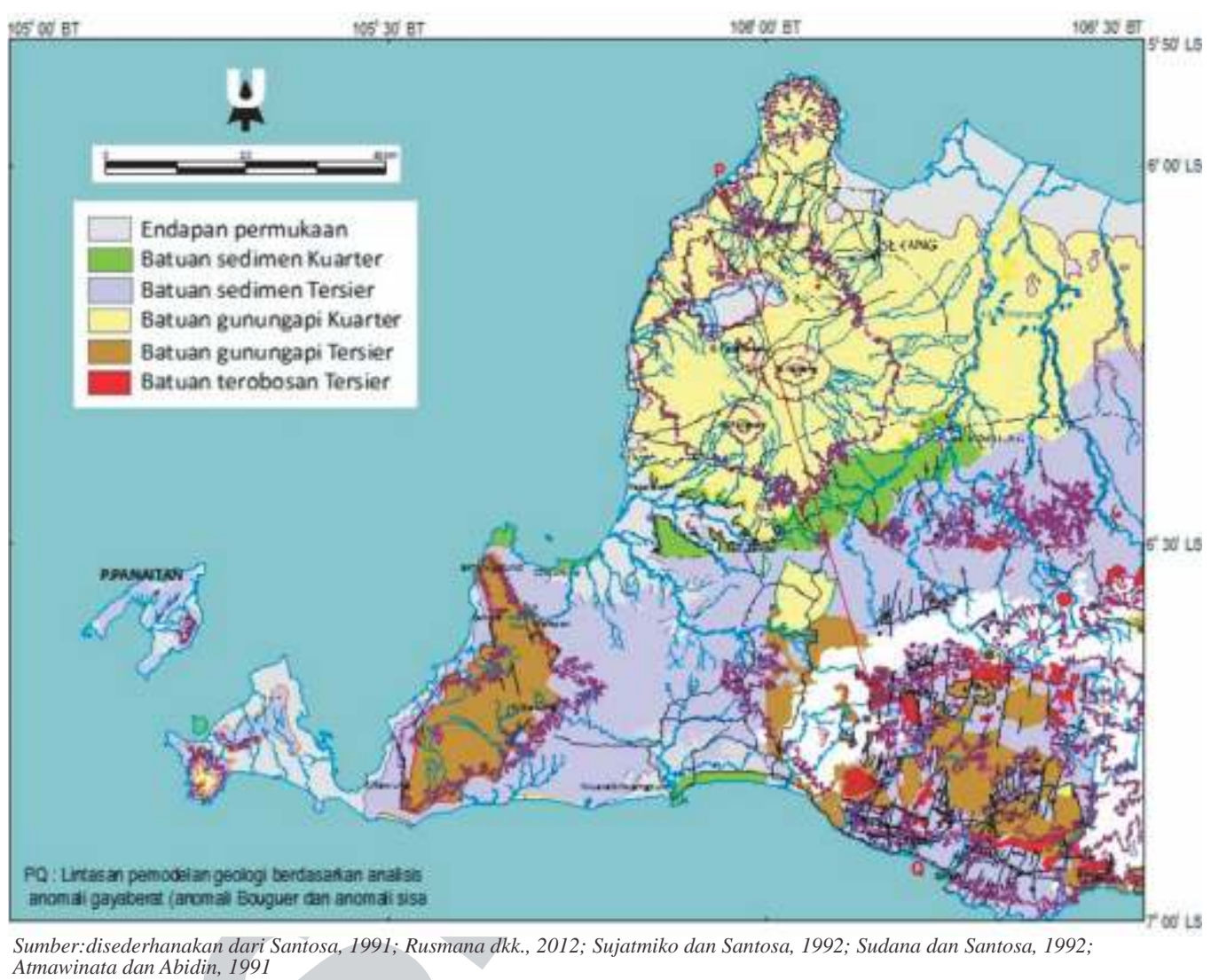

Gambar 2. Tatanan Geologi daerah penelitian.

Batuan sedimen tersingkap secara meluas di bagian tenggara daerah penelitian, berupa batuan sedimen Kuarter (tersingkap di daerah Rangkasbitung, tersingkap secara menyempit ke arah baratlaut, hingga daerah pantai barat daerah penelitian) dan batuan sedimen Paleogen-Neogen (tersingkap secara meluas ke arah selatan dari Rangkasbitung hingga pantai selatan). Satuan batuan tertua yang tersingkap di wilayah penelitian ini adalah Formasi Bayah yang berumur Eosen, bercirikan sedimen klastika kasar yang berasal dari rombakan batuan granit dan malihan dari Formasi Ciletuh, bersisipan batubara. batulempung-napal, dan batugamping.

Batuan gunungapi yang tersingkap di daerah penelitian, tersebar secara meluas di bagian utara, dan selatan. Di bagian utara, khususnya di sekitar G. Karang dan G. Pulasari tersingkap batuan gunungapi Kuarter. Batuan gunungapi Paleogen-Neogen tersingkap secara terpisah-pisah di bagian selatan, di sekitar pantai barat dan pantai selatan.

Batuan malihan yang tersingkap di daerah penelitian ini diduga berumur Oligo-Miosen, terdiri atas sekis, genes, amfibolit, dan granodiorit. Batuan terobosan yang tersingkap di daerah penelitian ini bersusunan andesit hingga basal, diduga terjadi hingga tiga kali terobosan, terobosan tertua terjadi di bagian selatan, dan makin ke utara umur terobosan makin muda, diperkirakan batuan terobosan ini berumur Paleogen-Neogen. Batuan terobosan diorit yang diduga berumur Kuarter menerobos Tuf Banten Bawah di G. Rangkong.

\section{Struktur dan Tektonik}

Pengaruh tektonik di daerah ini dicerminkan adanya lipatan, lipatan busur, sesar turun, sesar naik, sesar geser, sesar diagonal, dan sesar bongkah. Sumbu lipatan pada umumnya berarah barat - timur, baratlaut - tenggara, utara timurlaut - selatan baratdaya. Pada batuan tertua (Formasi Bayah, Formasi Bojongmanik), poros lipatan berarah utara timurlaut - selatan baratdaya. Sesar dan kelurusan pada umumnya berarah utara - selatan, barat timur, baratlaut - tenggara, umumnya berupa sesar turun dan sesar bongkah Dua sesar geser yang terdapat di P. Panaitan berarah timurlaut - baratdaya, diduga berhubungan dengan sesar-sesar di Sumatera (Rusmana dkk., 2012). 


\section{Sumberdaya Mineral dan Energi}

Sejak 1954 Unit Pertambangan Emas Cikotok PT Aneka Tambang mengusahakan penambangan emas, perak, timbal, seng, dan mineral bijih lainnya di daerah Banten Selatan. Daerah eksplorasi terutama terdapat di Cikotok, Cirotan, Hatemi, Lebak, Cipicung, Cikaret, Cimari, dan Pasir Malang. Sementara itu, batubara banyak terdapat di Formasi Bayah, Formasi Cijengkol, dan Formasi Bojongmanik, mencakup daerah Bayah, Cimandiri, Leuwidamar, dan Bojongmanik.

Mataair panas diketemukan di Desa Kareo, Anyer, dekat G. Batukuya, Jumungkal, di Desa Batukuwung, dan di puncak G. Pulosari, diperkirakan berasal dari rembesan dan sisa ubahan hidrotermal. Di wilayah Banten Selatan, seperti di Desa Cimanggoli dan Cisusuk, di sekitar G. Endut dan Cipanas dekat Cisolok, beberapa mataair panas mempunyai suhu sekitar $30^{\circ}-40^{\circ} \mathrm{C}$. Mataair panas yang keluar melalui sesar dan ditemukan di Desa Citando, Tamanjaya, dan Paniis (di bagian baratdaya daerah penelitian) mempunyai suhu antara $40^{\circ}-60^{\circ} \mathrm{C}$.

\section{METODOLOGI PENELITIAN}

Penelitian geofisika bermaksud melakukan penelitian kebumian dengan cara mempelajari sifat fisika dari batuan yang menyusun kerak bumi. Dalam metode gayaberat, sifat fisika batuan yang dipelajari adalah perbedaan kecil medan gayaberat yang diakibatkan oleh tidak meratanya densitas batuan di kerak bumi (Subagio, 2013).

Karena tidak beraturannya bidang fisika bumi, maka hasil pengukuran gayaberat di permukaan bumi tidak dapat langsung dihitung. Untuk keperluan itu, para ahli geodesi mendefinisikan model matematis bumi yang disebut elipsoid referensi. Elipsoid ini dinamakan World Geodetic Systems 1984 (WGS 1984). Selain bidang acuan ini, terdapat juga bidang acuan pengukuran yang didefinisikan sebagai geoid, merupakan bidang ekuipotensial gayaberat, yang mempunyai geometri sedemikian rupa sehingga bila ditarik garis tegak lurus terhadap permukaannya akan berhimpit dengan arah gayaberat. Garis arah gayaberat ini secara umum lebih dikenal sebagai garis vertikal.

Kedua bidang acuan tersebut (geoid dan elipsoid) sangat erat kaitannya dengan metode gayaberat, karena semua data ukuran gayaberat $\left(\mathrm{g}_{\mathrm{o}}\right)$ di muka bumi harus direduksi ke bidang acuan geoid. Reduksi dilakukan dengan cara memberikan beberapa koreksi, seperti: koreksi udara bebas, koreksi Bouguer, dan koreksi medan. Besarnya koreksi tersebut adalah:

- Koreksi udara bebas (kub): 0,3086 h (h: ketinggian titik ukur di atas muka laut rata-rata)

- Koreksi Bouguer (kb): 0,04193 ph ( $\rho$ : densitas batuan/kerak bumi di daerah penelitian)

- Koreksi medan $(\mathrm{km})$ : dihitung menggunakan Hammer Chart dan peta dasar topografi.

Berbeda dengan gayaberat ukuran $\left(\mathrm{g}_{\mathrm{o}}\right)$, terdapat pula gayaberat teoritis (gayaberat normal), merupakan nilai gayaberat di suatu titik tertentu di atas bidang elipsoid referensi (WGS 1984). Nilai gayaberat ini dapat dihitung menurut persamaan matematik yang merupakan fungsi dari lintang titik ukur. Persamaan tersebut adalah (Kahar, 1997; dalam Subagio, 2000):

$$
\begin{aligned}
\mathrm{G}_{\mathrm{n}}= & 9780326,771\left(1+0,0053014 \sin ^{2} \mathrm{~L}-0,0000059\right. \\
& \left.\sin ^{2} 2 \mathrm{~L}\right)
\end{aligned}
$$

Dengan demikian terdapat dua jenis gayaberat, yaitu gayaberat ukuran yang sudah direduksi ke bidang acuan dan gayaberat hitungan (gayaberat normal), perbedaan keduanya disebut sebagai anomali Bouguer. Secara umum, anomali Bouguer dapat dihitung berdasarkan formula berikut ini (Heiskanen \& Moritz, 1966):

Anomali Bouguer $=g_{o}-G_{n}+k u b-k b+k m$

\section{PemisahanAnomali Residual dan Regional}

Pada dasarnya anomali gayaberat yang terukur di permukaan merupakan gabungan (superposisi) dari berbagai macam sumber dan kedalaman anomali yang ada di bawah permukaan, salah satunya merupakan target untuk dipisahkan, baik yang berada di zona yang dangkal (residual) atau zona yang dalam (regional). Anomali residual merupakan anomali gayaberat yang diakibatkan oleh anomali dangkal yang mempunyai frekuensi spasial tinggi dan panjang gelombang yang pendek, sementara anomali regional adalah anomali gayaberat yang diakibatkan oleh anomali dalam yang mempunyai frekuensi spasial rendah dan panjang gelombang yang panjang (Telford dkk.,1990).

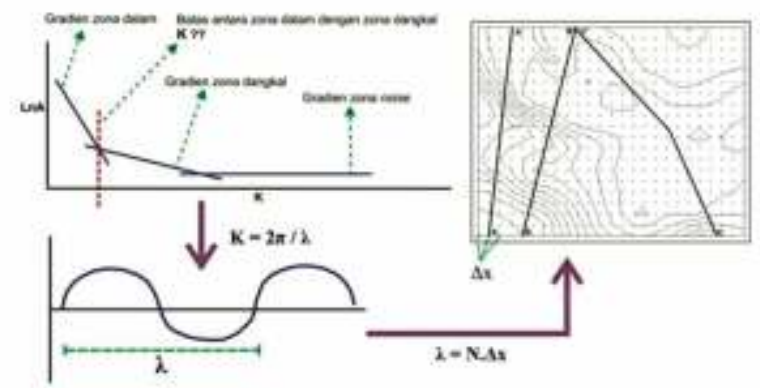

Gambar 3. Ilustrasi penentuan lebar jendela. K (bilangan gelombang sampling) pada gambar di atas adalah perioda transformasi Fourier, sedangkan $\mathrm{N}$ adalah lebar jendela (Blakely, 1996). 
Untuk dapat memisahkan anomali residual dan anomali regional, dapat dilakukan antara lain dengan metode perata-rataan bergerak (moving average), pendekatan persamaan polynomial, dan turunan vertikal orde dua (second vertical derivative). Di antara ketiga metode tersebut, metode perata-rataan bergerak (moving average) digunakan untuk mendapatkan anomali residual daerah penelitian, diproses melalui perangkat lunak Oasis Montaj. Pada dasarnya metode ini menghasilkan output berupa anomali regional, sehingga untuk mendapatkan anomali residual dilakukan dengan cara menghitung selisih anomali Bouguer dengan anomali regional. Pemisahan anomali dilakukan dengan menapis anomali gelombang frekuensi tinggi (low pass filter). Semakin lebar jendela yang digunakan maka nilai anomali residualnya akan mendekati nilai anomali Bouguer.

Hal yang pertama dilakukan untuk mengestimasi lebar jendela adalah membuat grid daerah penelitian dengan spasi tertentu. Data grid tersebut kemudian diolah untuk memperoleh nilai harga spektrum amplitudo dan frekuensi. Untuk mencari lebar jendela yang optimal, spektrum amplitudo yang dihasilkan transformasi Fourier tersebut di-logaritma-kan dengan basis bilangan natural sebagai ordinat dan nilai frekuensi dikalikan dengan $2 p$ untuk mendapatkan nilai bilangan gelombang sebagai absis, sehingga komponen $\mathrm{k}$ sebagai pangkat bilangan natural menjadi berbanding lurus dengan spektrum amplitudo. Dari persamaan garis lurus melalui regresi linier diperoleh batas antara orde satu (regional) dengan orde dua (residual), sehingga nilai $\mathrm{k}$ pada batas tersebut diambil sebagai penentu lebar jendela. Lebar jendela ditentukan sebesar 13.

\section{POLA ANOMALI GAYABERAT DAERAH PENELITIAN}

\section{Pola Anomali Bouguer}

Pemetaan sistematik gayaberat di daerah penelitian telah dilakukan sejak tahun 1990 - 1994, menghasilkan lima lembar peta skala 1:100.000, terdiri atas Lembar Anyer (Rohandi \& Nasution, 1990), Lembar Serang (Nasution \& Djaswadi, 1990), Lembar Leuwipanjang (Nasution \& Tasno, 1990), Lembar Cikarang (Rohandi \&n Lelitoly, 1990), dan Lembar Ujung Kulon (Simamora, 1994). Secara umum anomali Bouguer daerah penelitian bernilai sekitar 52 - $166 \mathrm{mGal}$, membentuk pola tinggian anomali di bagian selatan dan bagian utara, dan pola rendahan anomali di bagian tengah wilayah penelitian. Tinggian anomali di wilayah utara dikatakan sebagai Tinggian Tangerang, sedangkan tinggian di wilayah selatan dikatakan sebagai Tinggian Bayah (Sujanto \& Wahab, 1990). Rendahan anomali di bagian tengah dibangun oleh anomali sekitar 52.5 - 62.5 mGal, terletak disekitar daerah Pandeglang Rangkasbitung, mencerminkan suatu cekungan yang diduga terbentuk akibat keberadaan sesar, sehingga menyebabkan terjadinya suatu terban (graben). Rendahnya anomali di wilayah ini menggambarkan rendahnya densitas batuan yang mengisi terban tersebut, diduga merupakan batuan gunungapi yang telah teralterasi (Subagio dan Widijono, 2008).

Tinggian anomali di bagian selatan daerah penelitian dibangun oleh anomali tinggi, sekitar nilai 70-166 mGal, diduga diakibatkan oleh menipisnya fragmen kerak benua, dan meningginya moho oleh kinematika kompresi oblik di sekitar lajur penunjaman kerak Samudera Hindia (Sardjono \& Simandjuntak, 2004 dalam Subagio, 2018). Di samping itu, tingginya anomali juga diakibatkan oleh tersingkapnya batuan terobosan Paleogen-Neogen (andesit dan basal, serta granodiorit dan diorit) yang mempunyai densitas batuan tinggi (Sudana \& Santosa, 1991; Sujatmiko \& Santosa, 1992). Tinggian anomali di bagian utara daerah penelitian (dikenal sebagai Tinggian Tangerang) dibangun oleh anomali bernilai $70-82.5$ mGal, diduga diakibatkan oleh keberadaan batuan terobosan diorit, andesit dan basal (Santosa, 1992; Rusmana dkk., 2012).

Berdasarkan peta seismotektonik daerah Selat Sunda dan sekitarnya skala 1:500.000 (Soehaimi dkk., 2004), di daerah penelitian ini tersebar beberapa kelurusan sesar, antara lain sesar geser berarah baratlaut-tenggara, dimulai dari Kotaagung (Lampung), memotong wilayah Banten (sekitar Menes), berakhir di sekitar Sukabumi. Berdasarkan analisis anomali Bouguer, diduga sesar geser ini mengandung penyesaran ke arah vertikal, karena pola anomalinya di daerah ini bergradien tinggi.

\section{Pola Anomali Sisa}

Berbeda dengan anomali Bouguer yang dapat menggambarkan struktur geologi bawah permukaan dari struktur dalam hingga struktur dangkal, anomali sisa hanya menggambarkan struktur dangkal di sekitar permukaan saja, sehingga lebih mendekati struktur geologi yang disajikan dalam peta geologi. Pola anomali sisa diakibatkan oleh anomali dangkal, yang dapat diinterpretasikan sebagai gambaran struktur dangkal (Gambar 5).

Berdasarkan peta cekungan sedimen Indonesia (Badan Geologi, 2009 dalam Subagio, 2018) di wilayah Banten ini terdapat dua cekungan sedimen, yaitu Cekungan Jakarta dan Cekungan Ujung Kulon. Kedua cekungan ini secara jelas dapat diidentifikasi pada peta anomali sisa, seperti yang terlihat pada Gambar 5 . 


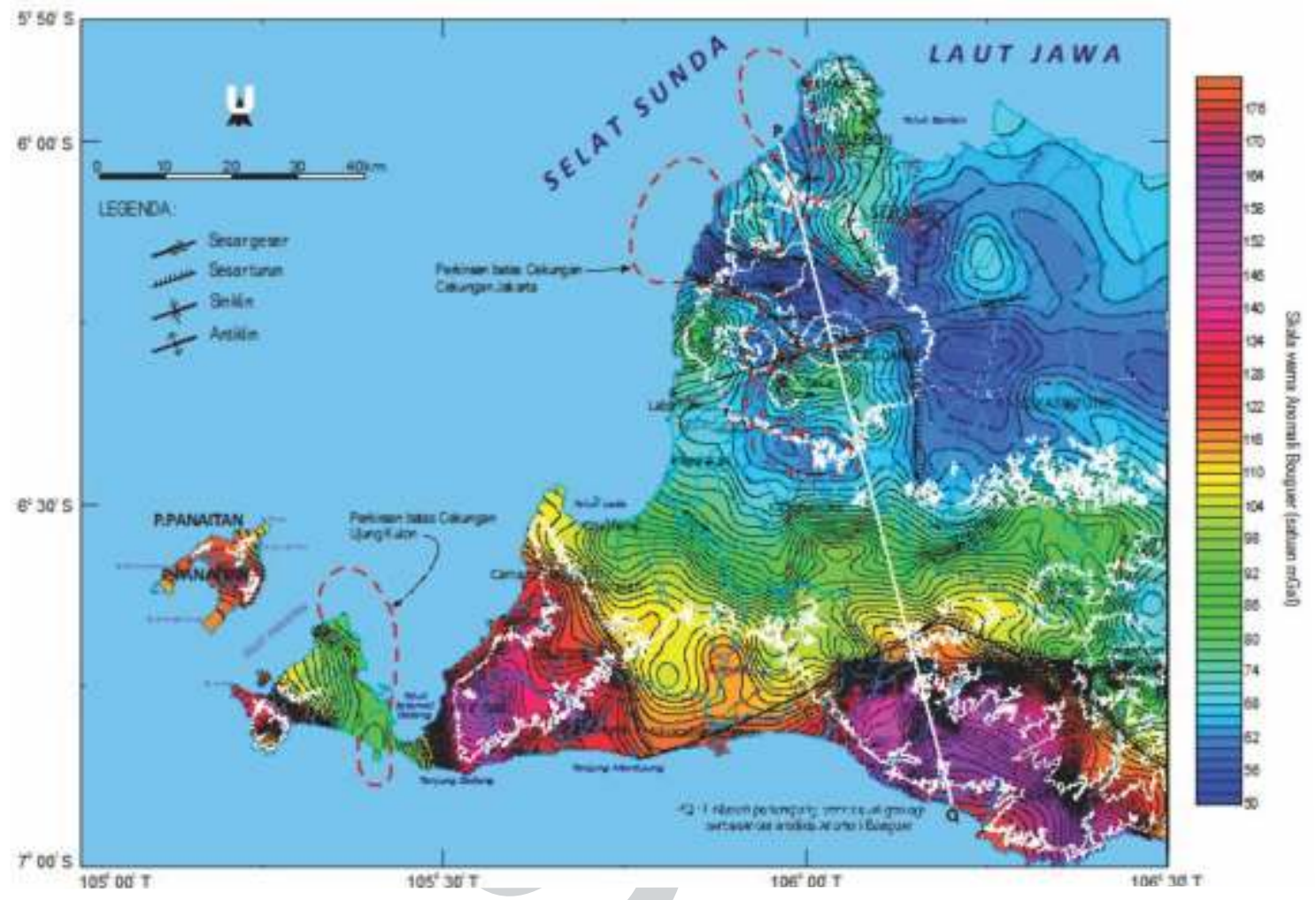

Gambar 4. Pola anomali Bouguer daerah penelitian dan sebaran sesar hasil analisis pola anomali.

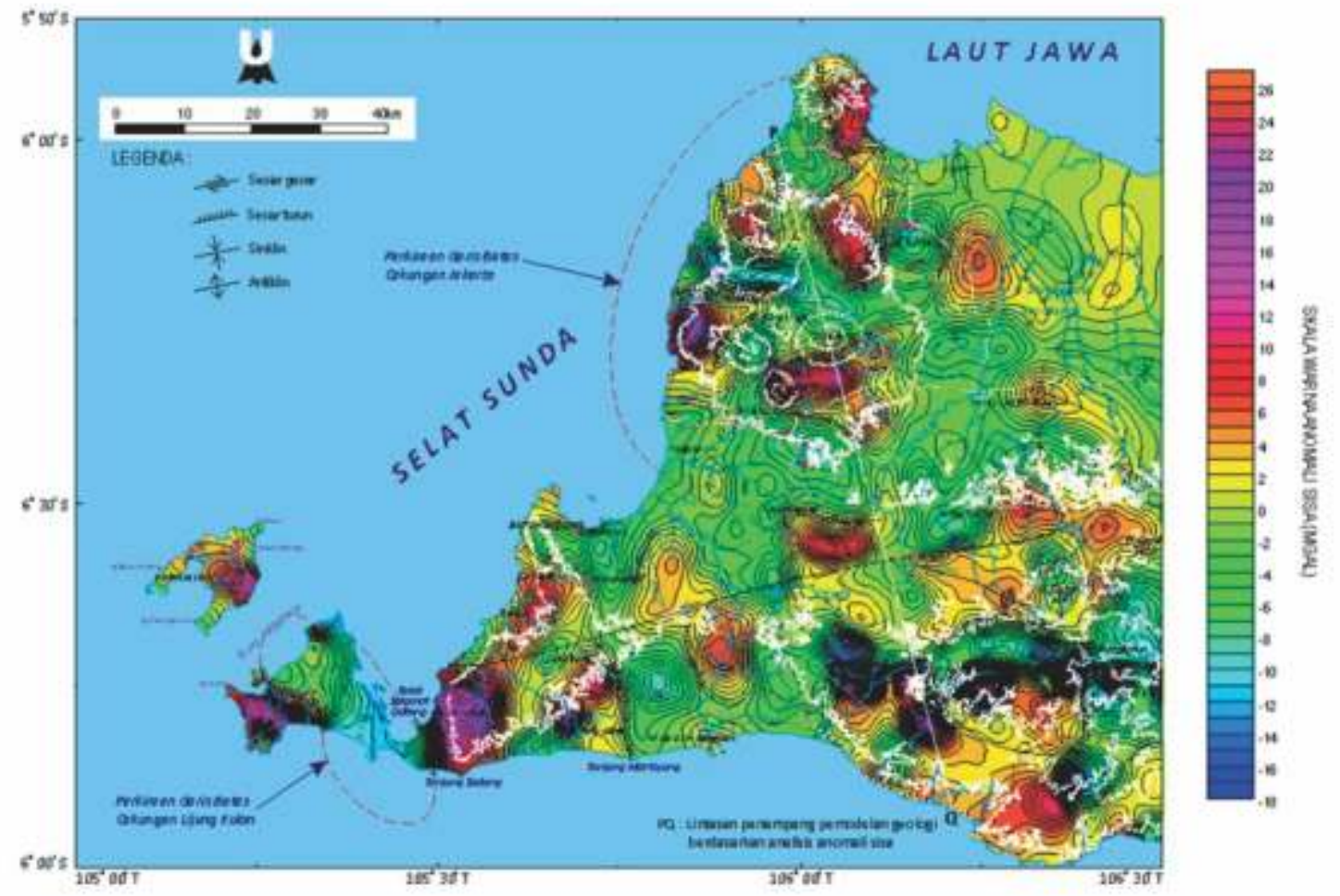

Gambar 5. Pola anomali sisa daerah penelitian dan sebaran sesar hasil analisis pola anomali. 
Delineasi batas Cekungan Jakarta dan Cekungan Ujung Kulon pada pola anomali sisa didasarkan atas keterdapatan gradien anomali terjal di sekitar batas tersebut, sebagai akibat adanya kontras densitas batuan. Kondisi ini hanya dapat terjadi bila ada kontak batuan yang mempunyai kontras densitas batuan yang tinggi, artinya terdapat kelurusan sesar di daerah ini. Gejala ini diduga adanya sesar turun yang mengakibatkan terjadinya graben di wilayah yang diduga sebagai wilayah cekungan sedimen tersebut di atas (Cekungan Ujung Kulon dan Cekungan Jakarta).

\section{Penafsiran Kuantitatif Pola Anomali Bouguer}

Pola anomali Bouguer daerah penelitian merupakan gambaran sebaran densitas batuan penyusun kerak bumi yang tidak merata di daerah tersebut, akibat terbentuknya struktur geologi bawah permukaan, dari struktur dalam hingga struktur dangkal. Penafsiran pola anomali secara kuantitatif dilakukan sepanjang lintasan PQ, yang ditarik dari pantai utara hingga pantai selatan daerah penelitian (Gambar 4).
Lintasan PQ ini digambarkan juga di atas Gambar 2, sehingga nampak memotong beberapa sesar di awal dan di akhir lintasan. Hasil analisis pola anomali secara kuantitatif, menunjukkan bahwa di sekitar km 20-35 terdapat struktur geologi berupa sesar turun yang menyebabkan terjadinya graben di sekitar interval km tersebut. Fenomena yang sama juga terjadi pada interval km 44-80. Struktur-struktur geologi ini tidak tersingkap pada data geologi permukaan yang diperlihatkan Gambar 2. Diperkirakan bahwa struktur geologi tersebut tertutupi oleh endapan batuan sedimen dan batuan gunungapi, sehingga tidak tersingkap ke permukaan.

Penampang anomali Bouguer sepanjang Lintasan PQ menunjukkan meningginya anomali ke arah pantai selatan (titik Q), yang diduga akibat meningginya mantel atas hingga kedalaman sekitar $7 \mathrm{~km}$ di sebelah selatan dari pantai selatan tersebut (sekitar km 114), serta menipisnya lapisan batuan sedimen di wilayah tersebut. Sementara ke arah pantai utara (titik P) ketebalan batuan sedimen semakin membesar, yang mengakibatkan anomalinya mengecil, karena densitas batuan sedimen relatif kecil(Gambar6).

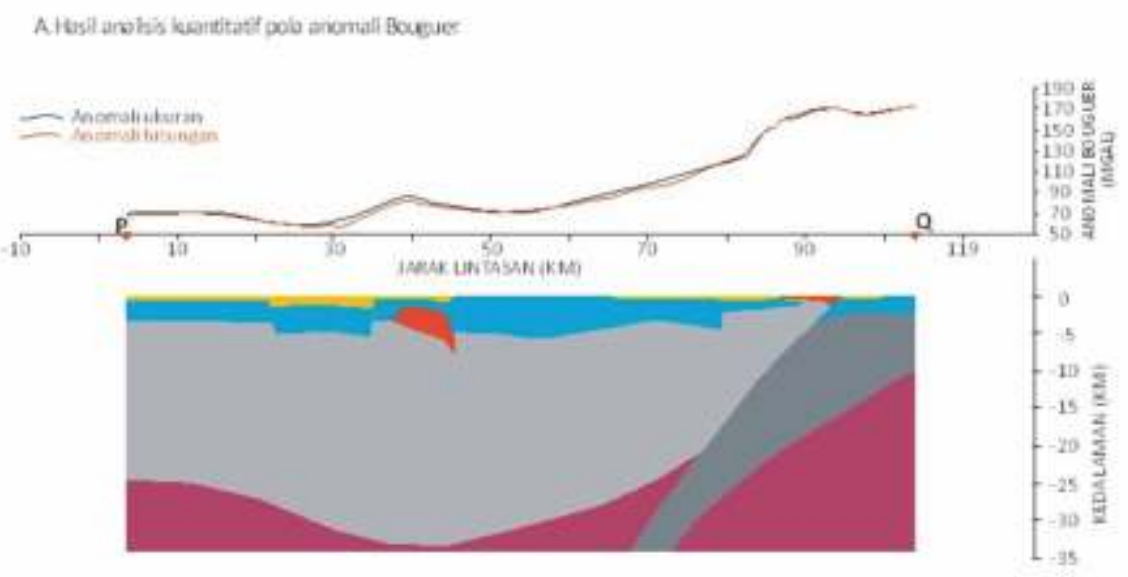

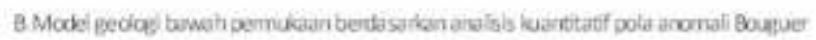

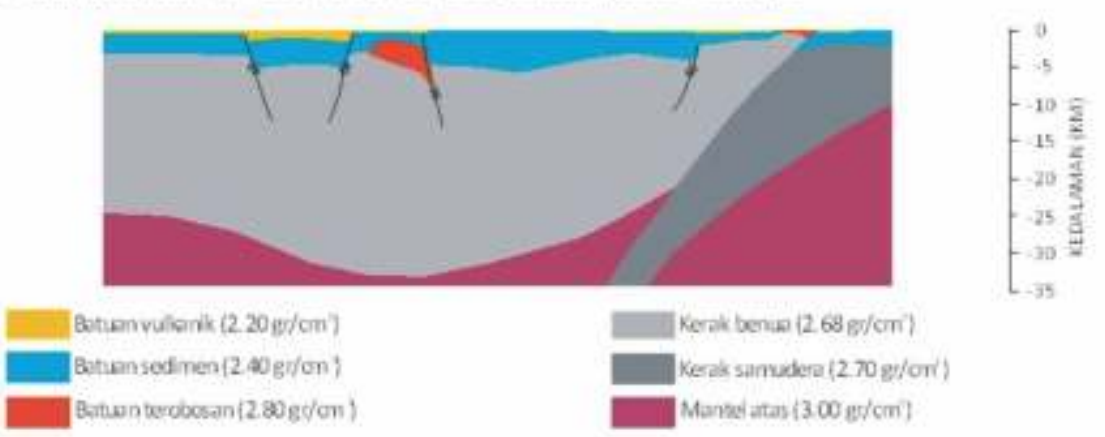

Gambar 6. Penampang pola anomali Bouguer sepanjang lintasan PQ dan gambaran struktur geologi bawah permukaan berdasarkan analisis anomali tersebut. 
A. Hasel analisis heantiratif pola anoenali sisa

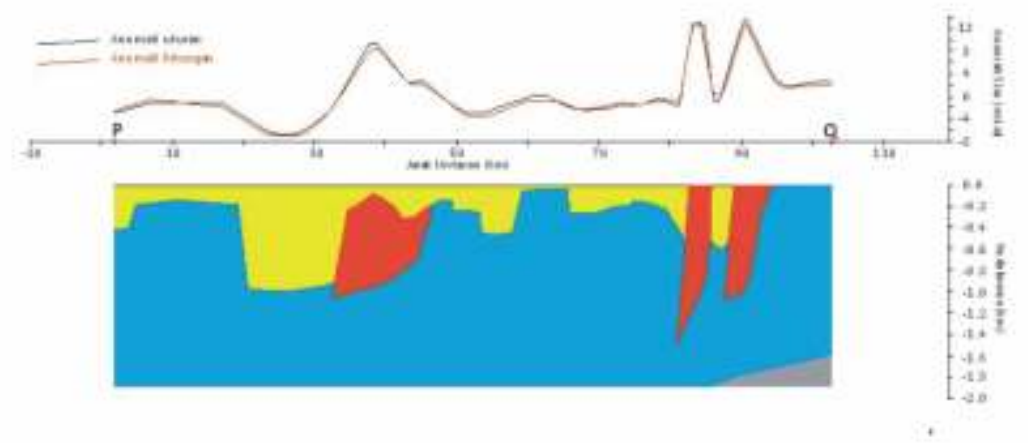

B. Model geologi tawah penmukan berdasarkan andisis huantitatif pola anomali sisa

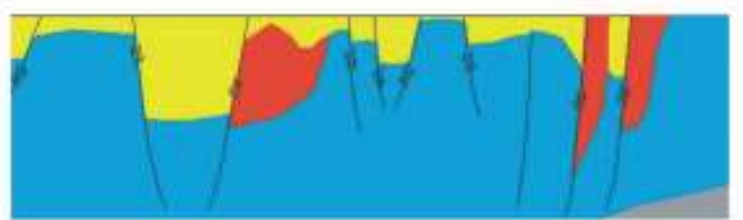

Keterangan:

Batuanchard $\left[0-22 \mathrm{~g} / \mathrm{cmi}^{\prime}\right]$

Batuan tooboian $(\rho=28 \mathrm{gr} / \mathrm{an})$

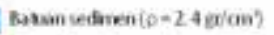

Eatasm berak samudera $(\rho=2,7 \mathrm{~g} / \mathrm{am}$ )

Gambar 7. Penampang pola anomali sisa sepanjang lintasan PQ dan gambaran struktur geologi di sekitar permukaan berdasarkan analisis anomali tersebut

\section{Penafsiran Kuantitatif Pola Anomali Sisa}

Berbeda dengan anomali Bouguer, anomali sisa pada dasarnya hanya menggambarkan sebaran densitas batuan yang tidak merata sebagai akibat terbentuknya struktur geologi di sekitar permukaan. Penafsiran pola anomali secara kuantitatif dilakukan sepanjang lintasan $\mathrm{AB}$, yang ditarik dari pantai utara hingga pantai selatan daerah penelitian (Gambar 7).

Penampang anomali sisa yang disajikan dalam Gambar 7 nampak tidak semulus penampang anomali Bouguer. Hal ini diduga akibat terbentuknya struktur geologi yang lebih komplek di permukaan, dibanding struktur geologi dalam yang didasarkan analisis anomali Bouguer (Gambar 6). Penampang anomali yang berundulasi dari $\mathrm{km0}$ (titik P) hingga km 104 (titik Q) sedemikian rupa, diperkirakan merupakan gambaran dari struktur geologi daerah penelitian berupa struktur terban yang terbentuk di beberapa tempat seperti terlihat pada gambar di atas (Gambar 7).

\section{PEMBAHASAN}

Secara umum anomali Bouguer daerah Banten digolongkan sebagai tinggian anomali. Secara khusus tinggian anomali ini dapat dikelompokkan ke dalam dua pola, pola punggungan dan pola cekungan anomali. Kedua pola anomali ini dipisahkan oleh pola anomali menjalur yang mempunyai gradien anomali relatif tinggi, sehingga dapat diinterpretasikan sebagai kelurusankelurusan sesar yang diduga merupakan sesar turun yang membentuk struktur terban di dua lokasi, yaitu Cekungan Jakarta dan Cekungan Ujung Kulon (Gambar 4 dan Gambar 5).

Tinggian anomali yang terjadi di sekitar G. Karang dan G. Pulasari (sekitar Pandeglang) diduga diakibatkan oleh tubuh batuan terobosan Kuarter yang diperkirakan sebagai sumber panas sistem panasbumi di wilayah tersebut. Pendugaan ini didasarkan atas hasil penelitian sebelumnya berupa penelitian geofisika terpadu yang melibatkan metode aeromagnetik, geolistrik, survei magneto-telluric sounding, survei gayaberat, dan pengukuran gradien panas bumi (Sudarman, 1985). 
Batuan sedimen Formasi Bojongmanik yang dominan mengandung batupasir dapat berfungsi sebagai batuan reservoir dari sistem panas bumi tersebut. Batuan penutupnya diperkirakan merupakan batuan gunungapi Kuarter yang sudah teralterasi oleh sistem panasbumi (Subagio \& Widijono, 2008). Tinggian anomali ini dapat dilihat dari pola anomali Bouguer (Gambar 4) maupun anomali sisa (Gambar 5), sehingga dapat diduga bahwa sistem batuan terobosan di atas berasal dari struktur geologi dalam yang menerus hingga mendekati permukaan. Di permukaan batuan ini tertutupi oleh batuan gunungapi Kuarter.

Tinggian anomali (anomali Bouguer maupun sisa) di sekitar pantai selatan yang terpotong lintasan PQ (di sekitar titik Q) diperkirakan diakibatkan oleh batuan terobosan Granodiorit Cihara yang menerobos Formasi Cikotok, dan diduga sebagai pembawa mineral bijih, seperti emas, perak, dan mineral bijih lain yang terdapat di daerah tersebut. Batuan terobosan tersebut terletak pada jalur anomali magnet rendah, yang diperkirakan disebabkan oleh kerentanan rendah dari batuan sedimen dan batuan gunungapi, serta batuan terobosan yang bersifat asam. Patut diduga bahwa batuan terobosan tersebut berperan besar dalam proses terjadinya mineralisasi logam sulfida seperti emas ( $\mathrm{Au}$ ) dan perak (Ag) di daerah Cikotok dan Cirotan (Simamora, 2006).

Di daerah Cibaliung Kabupaten Pandeglang, yang terletak di daerah kompleks vulkanik berumur Miosen, terdapat dua urat kuarsa (Urat Cikoneng dan Urat Cibitung) yang ekonomis untuk ditambang. Mineralisasi di daerah ini termasuk tipe sulfidasi rendah. Keberadaan emas pada sistem ini terletak pada urat sebagai tempat terakumulasinya unsur ini. Keterdapatan urat sendiri disebabkan adanya zona bukaan yang muncul akibat proses deformasi yang diisi oleh fluida hidrotermal dalam batuan pembawa mineralisasi (Bari dkk., 2020)

Di samping prospek potensi positif yang telah dibahas di beberapa alinea di atas, berikut ini potensi negatif yang dimiliki daerah penelitian. Berdasarkan hasil analisis secara kualitatif dan kuantitatif pola anomali Bouguer dan pola anomali sisa, terlihat bahwa di beberapa tempat dijumpai pola anomali menjalur yang mempunyai gradien anomali relatif tinggi. Fenomena ini dapat diinterpretasikan sebagai pertanda adanya kontras rapatmassa yang relatif tinggi juga. Artinya di lokasi tersebut terjadi kontak batuan yang mempunyai perbedaan densitas relatif tinggi, atau dengan perkataan lain terjadinya struktur sesar di daerah tersebut (Gambar 4 dan Gambar 5). Berdasarkan peta seismotektonik daerah Selat Sunda dan sekitarnya skala 1:500.000 (Soehaimi dkk., 2004), di daerah penelitian ini tersebar sesar-sesar berarah baratlaut-tenggara dan baratdaya-timurlaut. Salah satu sesar yang berarah baratlaut-tenggara dinyatakan dalam peta tersebut sebagai sesar geser, bermula dari Kotaagung (Lampung) melalui Selat Semangko, memotong Selat Sunda, berlanjut ke daerah Banten hingga mendekati arah Sukabumi. Sesar geser ini diperkirakan dapat pula diidentifikasi berdasarkan pola anomali Bouguer (Gambar 4) dan juga pola anomali sisa (Gambar 5). Namun, sesar ini tidak tampak pada peta geologi permukaan (Gambar 2), karena tertutupi oleh batuan sedimen Paleogen-Neogen dan batuan gunungapi Kuarter dan Paleogen-Neogen.

Berhubung sesar geser di atas dapat juga diidentifikasi berdasarkan pola anomali sisa, maka dapat diartikan bahwa sesar tersebut tergolong sebagai sesar dalam yang menerus hingga mendekati permukaan. Kondisi ini dapat menimbulkan kebencanaan geologi, bila ternyata sesar tersebut merupakan sesar aktif. Berdasarkan analisis seismotektonik yang berbasis pada kondisi geotektonik dan kegempaan sebagai dasar penentuan lajur-lajur potensi bencana gempa bumi, diketahui bahwa daerah penelitian ini memiliki potensi tinggi bencana geologi. Beberapa sesar aktif dijumpai di daerah penelitian ini adalah Patahan Aktif Banten dan di daerah sekitarnya meliputi Patahan Aktif Cimandiri, Patahan Aktif Citarik, Patahan Aktif Panaitan-Rajabasa (Soehaimi dkk., 2011).

\section{KESIMPULAN}

Pola anomali Bouguer daerah Banten pada dasarnya merupakan tinggian anomali Jawa bagian barat, karena secara regional pola anomalinya membentuk punggungan anomali. Sementara itu, bagian utara dari pola anomali Jawa bagian barat tersebut membentuk cekungan anomali, dan bagian selatannya membentuk punggungan anomali. Namun demikian, di wilayah tinggian anomali Banten ini terdapat juga pola anomali yang membentuk cekungan anomali, yaitu Cekungan Jakarta dan Cekungan Ujung Kulon.

Pola anomali sisa daerah Banten menunjukkan struktur geologi di sekitar permukaan, sebagian berhubungan langsung dengan pola anomali Bouguer, seperti yang memperlihatkan pola cekungan (Cekungan Jakarta dan Cekungan Ujung Kulon) dan pola punggungan anomali. Artinya, struktur geologi yang diperlihatkan oleh pola anomali Bouguer (struktur dalam) berlanjut hingga ke permukaan (sebagaimana diperlihatkan oleh pola anomali sisa). 
Pola-pola cekungan anomali di atas, pada umumnya terletak di bagian utara, dipisahkan dari pola punggungan anomali (terletak di bagian selatan) oleh suatu kelompok anomali menjalur yang mempunyai gradien anomali relatif tinggi yang dapat ditafsirkan sebagai struktur sesar. Struktur geologi yang telah digambarkan merupakan sesar geser yang berlanjut ke Selat Sunda, ke Selat Semangko, dan berujung di Kotaagung, Lampung.

\section{SARAN DAN REKOMENDASI}

Berdasarkan analisis pola anomali gayaberat, di daerah penelitian tersebar kelurusan pola anomali menjalur yang diidentifikasi sebagai struktur sesar. Selain menimbulkan potensi positif, kelurusan anomali menjalur tersebut juga diduga dapat menimbulkan potensi negatif. Untuk itu perlu penelitian lebih lanjut tentang keaktifan struktur sesar tersebut. Penelitian lanjutan yang diperlukan untuk mengetahui keaktifan sesar diperlukan penelitian menggunakan metode geofisika (mikrotremor) dan metode geodesi (penelitian GPS diferensial). Penelitian ini sebaiknya dilakukan secara monitoring, artinya dilakukan secara berulang, misalnya periode tiga bulanan, sehingga perubahan nilainya dapat diketahui secara berkala. Agar penelitian ini dapat berlangsung dengan optimal, maka perlu dibangun titik kontrol penelitian, di atas pilar beton bertulang, yang tersebar secara merata di sekitar sesar yang diteliti tersebut, serta terletak di lokasi yang stabil dan aman dari gangguan.

\section{UCAPAN TERIMA KASIH}

Makalah ini disusun berdasarkan data gayaberat yang yang dihimpun dalam basis data gayaberat Pusat Survei Geologi, baik hasil pemetaan sistematik gayaberat, maupun hasil penelitian rinci gayaberat. Untuk itu, kami ucapkan terima kasih kepada Kepala Pusat Survei Geologi atas izin penggunaan data tersebut, serta kepada para ahli gayaberat yang telah melakukan pengambilan dan pengolahan data tersebut.

\section{KONTRIBUTOR PENYUSUN MAKALAH}

Sebagai kontributor utama penyusunan makalah adalah Subagio, sedangkan kontributor anggota adalah $\mathrm{M}$. Ervan.

\section{ACUAN}

Atmawinata, S. dan Abidin, H.Z, 1991. Geologi Lembar Ujung Kulon, Jawa Barat Skala 1:100.000. Pusat Penelitian dan Pengembangan Geologi,Bandung

Bari, A., Rosana, M.F., dan Haryanto, I., 2020. Kontrol Struktur Geologi Pada Alterasi dan Mineralisasi di Daerah Cibaliung, Kabupaten Pandeglang, Provinsi Banten. Buletin Sumber Daya Geologi, 15(2): 73-87.

Blackely, R.J., 1996. Potential Theory in Gravity and Magnetic Application. Cambridge, University Press, pp.128-153,

Heiskanen, W.A. and Moritz, H., 1966. Physical Geodesy. W.H. Freeman and Company, San Franscisco and London, p.1-131.

Nasution, J. dan Tasno, D.P., 1990. Peta Anomali Bouguer Lembar Leuwidamar, Jawa, Skala 1:100.000. Pusat Penelitian dan Pengembangan Geologi, Bandung

Nasution, J. dan Djaswadi, I., 1990. Peta Anomali Bouguer Lembar Serang, Jawa, Skala 1:100.000. Pusat Penelitian dan Pengembangan Geologi, Bandung

Rohandi, U. dan Nasution, J., 1990. Peta Anomali Bouguer Lembar Anyer, Jawa, Skala 1:100.000. Pusat Penelitian dan Pengembangan Geologi, Bandung

Rohandi, U. dan Lelitoly, D., 1990. Peta Anomali Bouguer Lembar Cikarang, Jawa, Skala 1:100.000. Pusat Penelitian dan Pengembangan Geologi, Bandung

Rusmana, E., Suwitodirdjo, K., dan Suharsono, 2012. Geologi Lembar Serang, Jawa, Skala 1:100.000. Pusat Penelitian dan Pengembangan Geologi, Bandung

Santosa. S., 1992. Geologi Lembar Anyer, Jawa Barat, Skala 1:100.000. Pusat Penelitian dan Pengembangan Geologi, Bandung

Simamora, W.H., 1994. Peta Anomali Bouguer Lembar Ujung Kulon, Jawa, Skala 1:100.000. Pusat Penelitian dan Pengembangan Geologi, Bandung 
Simamora, W.H., 2006. Anomali Geomagnet, Kaitannya dengan Zone Mineralisasi di Daerah Malingping, Bayah, dan sekitarnya, Kabupaten Lebak, Propinsi Banten. Jurnal Sumber Daya Geologi, 16(5): 285-301.

Soehaimi, A., Effendi, I., Djuhanda, A., Hayat, D.Z., dan Hutubessy, S., 2004. Peta Seismo Tektonik Daerah Selat Sunda dan sekitarnya, Skala 1:500.000. Pusat Penelitian dan Pengembangan Geologi, Bandung.

Soehaimi, A., Marjiyono, Soemantri, P., dan Kamawan, 2011. Geodinamika dan PotensiBahaya Gempabumi Dalam Rangka Pembangunan Jembatan Selat Sunda. Proceedings JCM Makassar, The 36th and 40th IAGI Annual Convention and Exhibition, Makassar, 26-29 September 2011.

Subagio dan Widijono, B.S., 2008. Potensi Panas Bumi Daerah Pandeglang dan Sekitarnya Berdasarkan Evaluasi Data Geologi dan Geofisika Terpadu. Jurnal Sumber Daya Geologi, 18(3): 135-148.

Subagio, 2013. Pola Anomali Bouguer Jawa Barat Implikasi Terhadap Potensi Geologi. Makalah Presentasi Karya Ilmiah Rangkuman Hasil Penelitian, Pusat Survei Geologi, Bandung

Subagio, 2018. Struktur Geologi Bawah Permukaan Pegunungan Selatan Jawa Barat Ditafsir dari Anomali Bouguer, Jurnal Geologi dan Sumberdaya Mineral, 19(4): 183-196.

Sudana, D. dan Santosa. S., 1991. Geologi Lembar Cikarang, Jawa, Skala 1:100.000. Pusat Penelitian dan Pengembangan Geologi, Bandung

Sudarman, S., 1985. Sub-surface Interpretation at Proposed First Deep Wellsite Citaman Geothermal Area, Banten, West Java. Proceedings Indonesian Petroleum Association, Fourtheenth Annual Convention.

Sujanto, F.X. and Wahab. A, 1990. Tectonic Style, Sea Level, Changes and Sedimentation of The North West Java Basin Onshore Area. Pertamina, Jakarta

Sujatmiko dan Santosa, S., 1992. Geologi Lembar Leuwidamar, Jawa Barat, Skala1:100.000. Pusat Penelitian dan Pengembangan Geologi, Bandung

Telford, W.M., Geldard, L.P., and Sheriff, R.E, 1990. Applied Geophysics. Cambridge, University Press, pp.26-27. 